\title{
Characterization and Prediction of Continuous Cooling Transformations in Rail Steels
}

\author{
Karine Fernandes Rodrigues ${ }^{a}$, Geraldo Lúcio de Faria ${ }^{a}$ (D) \\ ${ }^{a}$ Universidade Federal de Ouro Preto, Campus Universitário do Morro do Cruzeiro, 35400-000, Ouro \\ Preto, MG, Brasil.
}

Received: November 13, 2020; Revised: May 28, 2021; Accepted: June 04, 2021

\begin{abstract}
This paper presents the characterization of austenite to pearlite transformation in rail steels (premium and standard) using dilatometry. The critical transformation temperatures were measured as a cooling rate function and the obtained microstructures were qualitatively and quantitatively characterized. Aiming to study the transformation kinetics, three equations proposed by technical literature were evaluated in order to predict the transformation evolution. Experimental and calculated CCT diagrams were compared. It was concluded once the kinetics of phase transformation in rail steels is well characterized, it can be used as reference to enable suitable heat treatment to obtain pearlitic microstructures for the standard steel as refined as those of premium. The minor prior austenite grain size of the standard steel favoured the pearlite nucleation, however its highest $\mathrm{Mn}, \mathrm{Nb}$ and $\mathrm{Si}$ contents delayed the growth stage. All equations evaluated in order to predict the kinetics of austenite to pearlite transformation under continuous cooling were satisfactory.
\end{abstract}

Keywords: Rail steel, Continuous cooling transformation, Phase transformation prediction, Dilatometry.

\section{Introduction}

Most of the production of ore and agricultural products around the world is increasingly being transported by railways across continents. Nowadays, with the continuous increase of train operation speed and transported axle load, the use of better rail steels and the improvement of welding techniques have been sought with the aim to increase the rail life and to decrease the cost of track maintenance. This actual need has been the driving force for recent developments and for the increasingly number of published studies addressing the improvement and innovation in rail steel manufacturing and welding ${ }^{1-7}$.

Pearlitic steels are widely used in the railway industry worldwide due to their good wear resistance and satisfactory toughness, in association with its relatively manufacturing low cost. The mechanical properties of pearlitic steels are controlled by the microstructures arising from their thermomechanical processing, especially by characteristics such as previous austenitic grain size, pearlite interlamellar spacing and pearlite colony size ${ }^{1-11}$. According to the AREMA $^{12}$, these rail steels presenting pearlitic microstructures can be classified into two classes: standard and premium. The classification criteria are the chemical characteristics and the final mechanical properties. The standard pearlitic rails, which have a relatively simple eutectoid chemical composition, present a relatively coarse interlamellar spacing, and for this reason, they hold relatively low hardness values, around $300 \mathrm{HB}$. On the other hand, the premium rails, with a better designed chemical composition, have more refined

*e-mail: geraldolfaria@yahoo.com.br microstructures and consequently higher hardness, which can range from 340 to $390 \mathrm{HB}^{11,12}$.

However, despite the actual technical knowledge about the pearlitic rail steels currently used worldwide, many authors highlight the recurrent occurrences of premature failures, causing great financial losses and, sometimes, even loss of human lives ${ }^{13-16}$. The most of these failures, according to them, are related to wear-tear, fatigue and welding problems $\mathrm{s}^{3,11,13-18}$. In this context, a relevant and contemporary challenge is to improve the mechanical performance of pearlitic rail steels without the need to increase project costs, avoiding the use of steel types with significant additions of alloying elements. According to some recent published studies, it is possible to improve the pearlitic rail performance improving its microstructural characteristics. For this purpose, authors have been pointing out the importance to well characterize and to understand the rail steel phase transformations aiming to better design the thermal cycles to which they are submitted during their manufacturing or welding processes ${ }^{1-5}$.

For example, recently, Rodrigues et al. ${ }^{2}$, studying the kinetics of isothermal phase transformations in rail steels, showed that, for the same austenitizing conditions, it is possible to obtain a pearlitic microstructure for a standard steel as refined as those of premium steels. According to them, this is possible due to the design of a well-planned thermal profile after rail hot rolling, considering the specificities of steel phase transformations as a chemical composition function. Porcaro et al. ${ }^{3}$, studying welding, identified three different microstructural regions composing the heat-affected zone of a rail welded joint. According to them, these areas represent a dangerous microstructural discontinuity and 
they are preferential sites for fatigue crack nucleation. Applying phase transformation concepts and a dilatometry based methodology, they explained the cause of these three different regions and proposed an alternative welding thermal cycle, focusing on a controlled post-weld cooling, in order to decrease this microstructural discontinuity. Godefroid et al. ${ }^{4}$, applying dilatometry and fatigue tests in order to compare a microalloyed rail steel with a common rail steel, showed that the vanadium presence in the microalloyed steel can provide a more refined pearlitic microstructure, improving the rail mechanical properties. However, they also verified that the use of an appropriate range of a simple chemical composition and a well-planned thermomechanical processing can provide a carbon steel, in accordance to standard specifications for railroad application ${ }^{12}$, i.e. without the need of microalloying element additions, with similar fatigue performance.

In this scenario where any small improvement on mechanical properties of pearlitic rail steels is relevant, the current trend to increasingly apply kinetics of phase transformation studies, in order to better design rail steel processing and to accurately achieve great microstructural and mechanical characteristics, has gotten stronger. Recent papers have shown that the accurate phase transformation methodologies applied, in a personalized way, to rail steels are great tools for this material improvement ${ }^{2-7}$. In this context, the current work presents a study about the characterization and prediction of continuous cooling transformations in three rail steels. The kinetics of austenite decomposition under continuous cooling were investigated and the effect of cooling rate on the final microstructure were studied. Aiming to evaluate and to propose predictability models in order to mathematically describe the evolution of continuous cooling transformation in the studied rail steels, mathematical models available in the literature were applied.

\section{Materials and Methods}

\subsection{Materials}

The present work investigated three types of rail steels, herein named as A, B and C. The chemical compositions of the studied steels are presented in Table 1. As abovementioned in the introductory section, the AREMA standard ${ }^{12}$ classifies the pearlitic rail steels into two classes: standard and premium. According to the manufacturers of the studied materials, the steels $\mathrm{A}$ and $\mathrm{B}$ are commercialized in the world as premium ones, while the $\mathrm{C}$ as a standard. Comparing the chemical compositions (Table 1) with the chemical specifications presented by AREMA ${ }^{12}$, one of the most important classification criteria, it is possible to state that steels $\mathrm{A}$ and $\mathrm{B}$ really meet the premium requirements and $\mathrm{C}$ the standard ones.

Evaluating Table 1, it can be observed that steel C presents the lowest carbon content and the highest $\mathrm{Mn}$ level when compared to steels A and B. As the premium steels are usually submitted to an accelerated cooling in a water spray system after its hot rolling, to obtain a fully and refined pearlitic microstructure, it is necessary to limit their hardenability in order to avoid martensitic transformation. The decrease of Mn and Si contents are a used strategy to achieve this. However, aiming to avoid the formation of proeutectoid ferrite, the carbon content must be slightly increased to meet the eutectoid composition ${ }^{2,4,19}$.

\subsection{Experimental procedures}

\subsubsection{Characterization of the as Manufactured Steels}

In order to characterize the steels in the as manufactured state, the sampling and the metallographic preparation procedures were performed in the transversal section in relation to the rail rolling direction. Samples were collected from a region placed at approximately $15 \mathrm{~mm}$ below the rail rolling surface, at the rail head. The steel samples were cut, mounted, sanded and polished according to procedures recommended by the ASTM E3 standard ${ }^{20}$. After sample preparation, chemical etching was performed with Nital $2 \%$ in order to reveal the microstructures. The microstructural analyses were performed in a scanning electron microscope (SEM) TESCAN VEGA3.

The average size of pearlite colonies (average equivalent diameter) and the average pearlite interlamellar spacing were determined for the studied steels. The pearlite colony size was determined by using the thermal etching technique in a controlled atmosphere furnace. The thermal etching was performed in a low oxygen partial pressure for 15 minutes at a temperature below $\mathrm{Ac}_{1}^{3,4}$. The etched samples were analysed by optical microscopy (OM) and the measurements were performed according to ASTM E112 ${ }^{21}$. The interlamellar spacing $(\lambda)$ was measured in SEM micrographs by analyzing the regions of smaller spacing, which will be the ones that the polishing plan will cut perpendicularly to the lamellar pearlite colonies ${ }^{3,4,22}$. The interlamellar spacing was obtained by Equation 1, where $V B$ is the real value of the scale bar ( $\mu \mathrm{m})$ present in all SEM images, $M B$ is the length of the scale bar measured in $\mathrm{mm}, M L$ is the length of the test line drawn perpendicularly to the lamellae $(\mathrm{mm})$ and $N L$ is the number of cementite lamellae counted along the drawn line. Three lines were used in each one of the 30 acquired images for the three studied steels, at a magnification of 20.000X, in order to produce representative average values.

Table 1. Chemical compositions of the studied steels (wt.\%).

\begin{tabular}{|c|c|c|c|c|c|c|}
\hline Steel & $\mathrm{C}$ & $\mathrm{Si}$ & $\mathrm{S}$ & $\mathrm{Mn}$ & $\mathrm{P}$ & $\mathrm{Cr}$ \\
\hline A & 0.792 & 0.304 & 0.0043 & 0.883 & 0.017 & 0.209 \\
\hline B & 0.763 & 0.223 & 0.0098 & 1.017 & 0.016 & 0.211 \\
\hline $\mathrm{C}$ & 0.731 & 0.539 & 0.0047 & 1.240 & 0.015 & 0.218 \\
\hline Steel & Mo & $\mathrm{Ni}$ & $\mathrm{Al}$ & $\mathrm{V}$ & $\mathrm{Nb}$ & $\mathrm{Ti}$ \\
\hline A & 0.016 & 0.02270 & 0.00530 & 0.0016 & 0.0022 & 0.0005 \\
\hline $\mathrm{B}$ & 0.000 & 0.01800 & 0.00300 & 0.0010 & 0.0000 & 0.0003 \\
\hline $\mathrm{C}$ & 0.017 & 0.02590 & 0.00630 & 0.0032 & 0.0170 & 0.0024 \\
\hline
\end{tabular}




$$
\lambda=\frac{\text { VB.ML }}{\text { MB.NL }}
$$

Vickers microhardness tests were performed in the as manufactured state samples. The average values were calculated from 10 measurements in each sample. The applied load was $200 \mathrm{gf}$ for $15 \mathrm{~s}$. The used apparatus was a Pantec, model HXD 1000TM microhardness tester.

\subsubsection{Experimental Determination of CCT Diagrams}

Dilatometric tests were performed with the aim to experimentally determine the continuous cooling transformation diagrams (CCT) for the three studied steels. For this purpose, dilatometry specimens were machined, for each studied steel, from the centre of the rail-head, in cylindrical shape with $3 \mathrm{~mm}$ in diameter and $10 \mathrm{~mm}$ in length. The change of specimen relative length $\left(\Delta \mathrm{L} / \mathrm{L}_{0}\right)$ was measured as a temperature function in a quenching dilatometer LINSEIS R.I.T.A. L78. In order to obtain representative CCT diagrams, for each studied steel, nine specimens were austenitized by continuous heating from room temperature to $900^{\circ} \mathrm{C}$ at $3^{\circ} \mathrm{C} / \mathrm{s}$. The soaking time at $900^{\circ} \mathrm{C}$ was $60 \mathrm{~s}$. Each austenitized sample was cooled to room temperature with a specific cooling rate. In this study, the evaluated cooling rates were $0.1^{\circ} \mathrm{C} / \mathrm{s}, 0.5^{\circ} \mathrm{C} / \mathrm{s}, 1^{\circ} \mathrm{C} / \mathrm{s}, 2.5^{\circ} \mathrm{C} / \mathrm{s}, 5^{\circ} \mathrm{C} / \mathrm{s}, 10^{\circ} \mathrm{C} / \mathrm{s}, 20^{\circ} \mathrm{C} / \mathrm{s}$, $50^{\circ} \mathrm{C} / \mathrm{s}$ and $100^{\circ} \mathrm{C} / \mathrm{s}$.

Based on the measured dilatometric curves, the critical temperatures of austenite to pearlite decomposition $\left(\mathrm{P}_{\mathrm{i}}\right.$ and $\mathrm{P}_{\mathrm{f}}$ ) were determined by the minimum deviation method ${ }^{23}$. The initial and final required time for austenite decomposition were determined by Equation 2, where $T \gamma$ is the austenitizing temperature $\left(900^{\circ} \mathrm{C}\right), \mathrm{T}$ is the measured critical temperature, and $R$ is the evaluated continuous cooling rate. After determining critical temperatures and transformation time intervals for each evaluated cooling rate, it was possible to determine the CCT diagrams for the three studied steels.

$t=\frac{T_{\gamma}-T}{R}$

For each studied steel, aiming to characterize the effect of cooling rate on final microstructures, the samples submitted to $0.5^{\circ} \mathrm{C} / \mathrm{s}, 2.5^{\circ} \mathrm{C} / \mathrm{s}$ and $10^{\circ} \mathrm{C} / \mathrm{s}$ were microstructurally characterized, by applying exactly the same qualitative and quantitative procedures used to perform the as-manufactured characterization. Vickers microhardness tests were also performed considering the same load and application time above-presented for as-manufactured sample.

As the prior austenite grain size is an important parameter that has a great influence on the CCT diagram and on the steel final microstructures, for the studied austenitizing condition, the prior austenite grains were metallographically revealed, as well as its average sizes were measured. In order to perform this characterization procedure, samples of each studied steel were heated to $900^{\circ} \mathrm{C}$ at $3^{\circ} \mathrm{C} / \mathrm{s}$ with 60 s soaking time. Then, each sample were quenched at $200^{\circ} \mathrm{C} / \mathrm{s}$ to room temperature. Samples were metallographically prepared according to ASTM E3 standard ${ }^{20}$ and etched with Teepol $(2 \mathrm{~g}$ of picric acid, $1 \mathrm{ml}$ of neutral surfactant, $1 \mathrm{ml}$ of hydrochloric acid and $100 \mathrm{ml}$ of distilled water $)^{24}$. The revealed prior austenite grains were evaluated in a LEICA DM2700M optical microscope and the average sizes were measured by applying the equivalent diameter semi-automatic method, according to ASTM E 112 and ASTM E1382 standards ${ }^{21,25}$. The LEICA LAS 4.6 software was used for this purpose.

\subsubsection{Kinetics of austenite continuous cooling decomposition}

In order to study the kinetics of austenite to pearlite decomposition, the dilatometric data acquired for all studied cooling rates were mathematically worked in OriginPro 9.0 software. The lever rule was applied to the relative length $\left(\Delta \mathrm{L} / \mathrm{L}_{0}\right)$ versus temperature data and the formed pearlite fraction was determined as temperature and time functions ${ }^{26,27}$. As classical performed for many authors in technical literature, aiming to obtain a predictability equation, in this study, the Johnson-Mehl-Avrami-Kolmogorov (JMAK) equation (Equation 3), adapted to continuous cooling transformations, was fitted to the obtained results. Where $\mathrm{X}$ is the formed pearlite fraction, $\mathrm{K}$ and $\mathrm{n}$ are fitting kinetics constants $^{27,28}$. For each studied steel, the $\mathrm{K}$ and $\mathrm{n}$ constants were determined as a cooling rate function.

$$
X=1-\exp \left(-K t^{\mathrm{n}}\right)
$$

Many researchers perform the mathematical adaptation of JMAK equation to predict continuous cooling phase transformations, even considering the physical understanding of the model is partially disregarded. Several authors stated that this mathematical adaptation, due to the sigmoidal profile of the JMAK equation, is an easy, simple and trustable way to model and to predict the phase transformations as a time function for a continuous cooled stee ${ }^{26,28-30}$. However, some authors also reported unsatisfactory fitting of JMAK equation to its experimental data, specifically for some steel types. They state that, eventually, a relatively low convergence occurs, leading to relatively low coefficient of determination $\left(\mathrm{R}^{2}\right)$ and, consequently, to great predictability deviations ${ }^{31-34}$.

Many published papers highlight alternative mathematical models to predict the continuous cooling transformations. Some of them are physically based ${ }^{35-38}$ and other consist of empirical equations ${ }^{31-34}$. In this study, aiming to compare and to evaluate simple and efficient tools to easily predict critical temperatures and the kinetics evolution of austenite to pearlite decomposition as a cooling rate function, two alternative equations were considered: a) Ferrite-time, proposed by Cezário ${ }^{31}$ and b) Empirical Model, proposed by Cezário et al. ${ }^{33}$. These empirical models were chosen because the authors stated they allow to well predict the kinetics of phase transformation and the steel CCT diagrams for the studied cooling rate range, without the need to use complex physical models or powerful computational resources.

In the Ferrite-time model, proposed by Cezário ${ }^{31}$, herein represented by Equation 4, $\mathrm{y}$ is the fraction of formed pearlite, $\mathrm{T} \gamma$ is the austenitizing temperature, $t$ is the elapsed time of the cooling beginning (the $t$ is considered 0 at the cooling beginning, at the end of austenitizing stage), $R$ is the evaluated continuous cooling rate, and $K^{\prime}, n$ ' and $\mathrm{T}_{f}$ are fitting constants. As JMAK equation, this model was also fitted 
to the experimentally obtained dilatometric data and fitting constants were determined for each evaluated cooling rate.

$y=\exp \left[-K^{\prime}\left(T \gamma+(-R . t)-T_{f}\right)^{n^{\prime}}\right]$

Both the JMAK and Ferrite-time equations allow to predict the pearlite fraction as a time function for each evaluated cooling rate. Using both models in order to predict the critical temperatures related to the pearlite formation, it was initially necessary to calculate two critical time intervals: a) the first, corresponding to the beginning of pearlite formation, was calculated considering $\mathrm{X}=\mathrm{y}=0.02$ in Equations 3 and 4, i.e. the need time to form $2 \%$ of pearlite; b) the second, corresponding to the end of pearlitic transformation, was determined assuming $\mathrm{X}=\mathrm{y}=0.9$ in Equations 3 and 4, i.e. $90 \%$ of pearlitic formation. After calculating critical time intervals ( $\mathrm{t}$ ), Equation 2 was used to estimate the critical transformation temperatures $(\mathrm{T})$ for each evaluated cooling rate, for the three studied steels. Considering that Equations 3 and 4 describes the phase fraction as a time ( $\mathrm{t}$ ) function during the transformation. If the parameter $t$ is calculated, it represents the transformation beginning time in relation to the cooling start if $\mathrm{X}=\mathrm{y}=0.02$ (value adopted in this paper) and it represents the transformation end time if $\mathrm{X}=\mathrm{y}=0.9$ (value adopted in this paper). As, for each experiment, the cooling rate $(\mathrm{R})$ was a constant, the temperature exactly at the instant t can be easily calculated applying the Equation 2 and it will represent the beginning transformation critical temperature for $\mathrm{X}=\mathrm{y}=0.02$ and the final transformation critical temperature for $\mathrm{X}=\mathrm{y}=0.9$.

However, these methodologies are limited to predict the critical temperatures because, once the constants of Equations 3 and 4 were determined by fitting to experimental data, the abovementioned equations would be able to predict the critical temperatures only for the exactly cooling rates applied in experiments. Hence, the Equation 5, named Empirical Model, proposed by Cezário et al. ${ }^{33}$, was also evaluated in this study. According to the authors ${ }^{33}$, this equation enables the prediction of the phase transformations critical temperatures directly as a cooling rate function. In Equation 5, T is the critical temperature; $y_{0}, A$ and $B$ are fitting constants and $R$ is the cooling rate. For each studied steel, this equation was twice employed. Initially, Equation 5 was fitted to $\mathrm{P}_{\mathrm{i}}$ (beginning temperature of austenite to pearlite transformation) versus $\mathrm{R}$ data, measured by dilatometry. Similarly, it was also fitted to $\mathrm{P}_{\mathrm{f}}$ (final temperature of austenite to pearlite transformation) versus R. These two fitting results, obtained for each investigated steel, allowed to easily predict the beginning and final temperature of austenite to perlite decomposition for any cooling rate at the studied range.

$T=y_{0}+A \cdot \exp (B \cdot R)$

Applying the results obtained from the fittings of Equations 3, 4 and 5 to the experimental data, it was possible to calculate the studied steel CCT diagrams. The calculated CCT diagrams were compared with the experimentally determined ones.

\section{Results and Discussion}

\subsection{Characterization of the as manufactured steels}

Figure 1 presents the SEM micrographs of steels A, B and $\mathrm{C}$. It is possible to observe that all evaluated structures are fully pearlitic. The studied steels presented homogeneous microstructures, having low content of MnS inclusions. These pearlitic microstructures were expected due to the material chemical compositions, near to eutectoid one. According to some authors, these type of rail steels, when subjected to non-equilibrium cooling in their manufacturing process, they have the formation of proeutectoid ferrite supressed ${ }^{2-4}$.

Recently, Rodrigues et al. ${ }^{2}$ performed computational simulation with the aim to evaluate the effect of chemical composition on the critical temperatures of phase transformations and on final microstructure of steels with the same chemical composition as those here studied. The authors used the Matcalc software to perform thermodynamic simulations in equilibrium conditions and showed that steels $\mathrm{A}, \mathrm{B}$ and $\mathrm{C}$ has really near eutectoid chemical compositions, i.e. even in an equilibrium cooling,
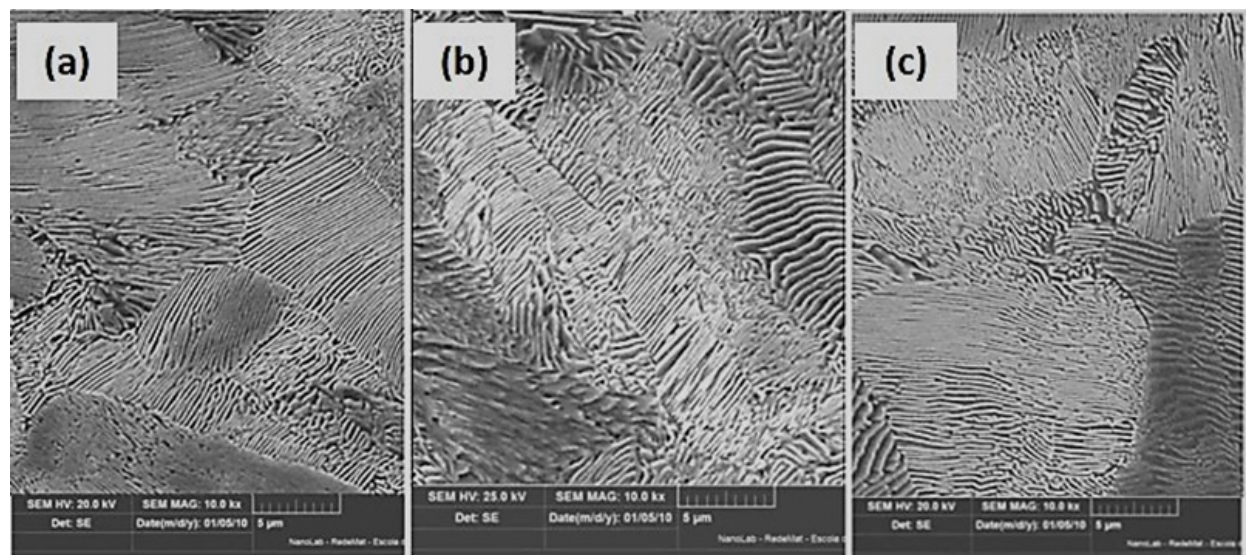

Figure 1. Microstructures of the as manufactured steels: (a) A, (b) B and (c) C - SEM - 10.000X - 2\% Nital etching. 
austenite majorly decomposes in pearlite. The authors also stated that, in an equilibrium condition, by comparing the $\mathrm{A}$, $\mathrm{B}$ and $\mathrm{C}$ steels, it is possible to affirm that $\mathrm{A}_{1}$ and $\mathrm{A}_{3}$ critical temperatures are similar. According to them, in this condition, the chemical composition is the only factor to be considered, so, the combined thermodynamic effect of the $\gamma$-genic and $\alpha$-genic elements in studied steels are responsible for this similarity. In this context, it is expected that in a non-equilibrium cooling, the thermodynamic effect of the elements will not be determinant to justify differences in the transformation temperatures, but their kinetic effects will do it.

The quantitative results obtained for pearlite interlamellar spacing, pearlite colony size and microhardness of steels A, B and $\mathrm{C}$ are shown in Table 2. Comparing the as manufactured conditions, it can be stated that steels A and B have the more refined microstructures, presenting the lowest values of colony size and interlamellar spacing. Due to these microstructural characteristics, they also have the highest hardness values. These results are in accordance with the technical literature ${ }^{2-4,17}$. According to the current rail manufacturing processes, after the rail hot rolling (similar rolling conditions for the three studied steels), steels A and B were continuous cooled under a water spray flow, which did not happen with steel $C^{2-4,17}$. It is important to also highlight that for steels A and B, the measured hardness values meet the premium rail class specification, while for the steel $\mathrm{C}$, it meets standard class ${ }^{12}$.

\subsection{Dilatometry}

\subsubsection{Austenite grain size}

As described in Materials and Methods section, for the studied austenitizing condition, the prior austenite grain sizes were measured. Figure 2 and Table 3 present the results obtained for the three studied steels. It is possible to observe that the differences between premium and standard steels are quite significant. The standard steel $\mathrm{C}$ presented the lowest prior austenite grain size, followed by the premium steel $\mathrm{A}$ and, finally by the premium steel B.

The prior austenite grain size is an important parameter that has a great influence on the CCT diagram and on the steel final microstructures ${ }^{39,40}$, therefore it is important to understand it. During the steel austenitizing from an original pearlitic microstructure, the most relevant structural factor to be considered is the pearlite interlamellar spacing ${ }^{2,41}$. During the pearlite to austenite diffusional transformation, the carbon diffusion occurs at average distances around the pearlite interlamellar spacing. As a result, the growth rate of austenite from pearlite increases as the interlamellar spacing decreases ${ }^{41-43}$. Besides that, Zhang et al. ${ }^{44}$ stated that in high carbon steels, the increase of $\mathrm{Mn}$ and $\mathrm{Cr}$ contents difficult the cementite dissolution, delaying the steel austenitizing. The higher $\mathrm{Nb}$ content in steel $\mathrm{C}$ also must be considered. As it is well known, the $\mathrm{Nb}$ both in solid solution or as precipitate contributes to decrease the austenite growth rate. In this scenario, the measured values of prior austenite grain sizes are coherent, since steels A and B, which presented the highest ones, had the most refined as manufactured pearlitic microstructures, as well as the lowest $\mathrm{Mn}, \mathrm{Cr}$ and $\mathrm{Nb}$ contents. Moreover, the solute drag effect of $\mathrm{Mn}, \mathrm{Nb}$ and $\mathrm{Si}$, elements found in greater amounts in steel $\mathrm{C}$, as well as the presence of $\mathrm{Nb}$ precipitates, might have contributed to restrain the austenitic grain growth in steel $\mathrm{C}^{45-48}$

\subsubsection{Experimental determination of CCT diagrams}

Figure 3 presents examples of dilatometric curves measured for the steels $\mathrm{A}, \mathrm{B}$ and $\mathrm{C}$ cooled at $5^{\circ} \mathrm{C} / \mathrm{s}$. In this figure, it is possible to observe the determination of critical temperatures by applying the minimum deviation method ${ }^{23}$. For the three evaluated steels, at this cooling rate, two different transformations were verified, that were: austenite to perlite decomposition (higher temperatures) and austenite to martensite transformation (lower temperatures). These transformations stand out in Figure 3 due to the expansions in the $\Delta \mathrm{L} / \mathrm{L}_{0}$ versus $\mathrm{T}$ curves. At $5^{\circ} \mathrm{C} / \mathrm{s}$ cooling rate, for example, the beginning temperatures related to austenite to pearlite decomposition $\left(\mathrm{P}_{\mathrm{i}}\right)$ are $662^{\circ} \mathrm{C}, 688^{\circ} \mathrm{C}$ e $705^{\circ} \mathrm{C}$, respectively, for steels $\mathrm{A}, \mathrm{B}$ and $\mathrm{C}$. However, at this cooling rate, for the three studied steels, some fraction of metastable austenite was carried out until relatively low temperatures,

Table 2. Average pearlite colony size, pearlite interlamellar spacing and Vickers hardness for steels $\mathrm{A}, \mathrm{B}$ and $\mathrm{C}$ as manufactured.

\begin{tabular}{cccc}
\hline Steel & $\begin{array}{c}\text { Pearlite } \\
\text { colony size } \\
(\mu \mathrm{m})\end{array}$ & $\begin{array}{c}\text { Pearlite } \\
\text { interlamellar } \\
\text { spacing }(\mu \mathrm{m})\end{array}$ & $\begin{array}{c}\text { Vickers } \\
\text { Hardness } \\
(\mathrm{HV})\end{array}$ \\
\hline $\mathrm{A}$ & $28 \pm 2$ & $0.09 \pm 0.01$ & $397 \pm 16$ \\
\hline $\mathrm{B}$ & $38 \pm 4$ & $0.15 \pm 0.03$ & $361 \pm 18$ \\
\hline $\mathrm{C}$ & $43 \pm 3$ & $0.18 \pm 0.03$ & $325 \pm 15$ \\
\hline
\end{tabular}

Table 3. Prior austenite grain sizes measured for steels A, B and C.

\begin{tabular}{cc}
\hline Steel & Prior austenite grain sizes $(\mu \mathrm{m})$ \\
\hline A & $25 \pm 11$ \\
\hline B & $34 \pm 15$ \\
\hline C & $13 \pm 6$ \\
\hline
\end{tabular}
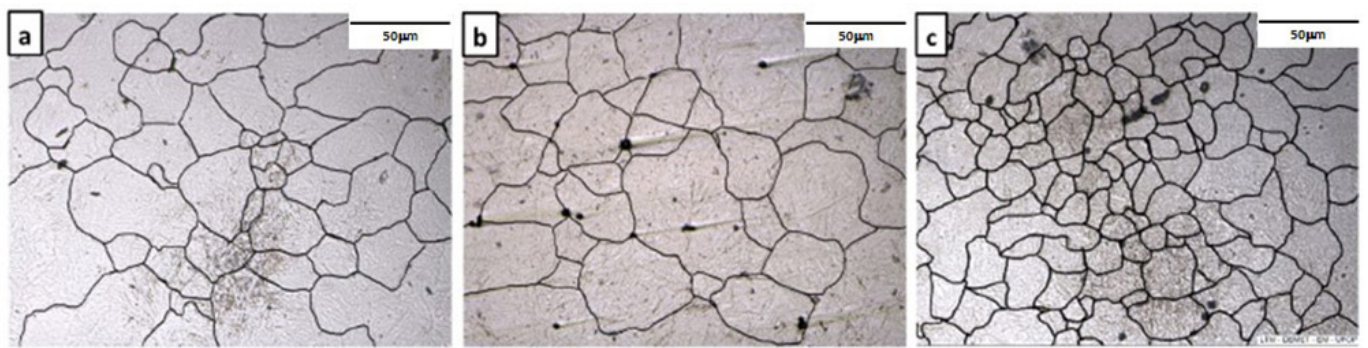

Figure 2. Prior austenite grains revealed for steels: (a) A, (b) B and (c) C - OM - 500X - Teepol etching and threshold contrast adjustment. 

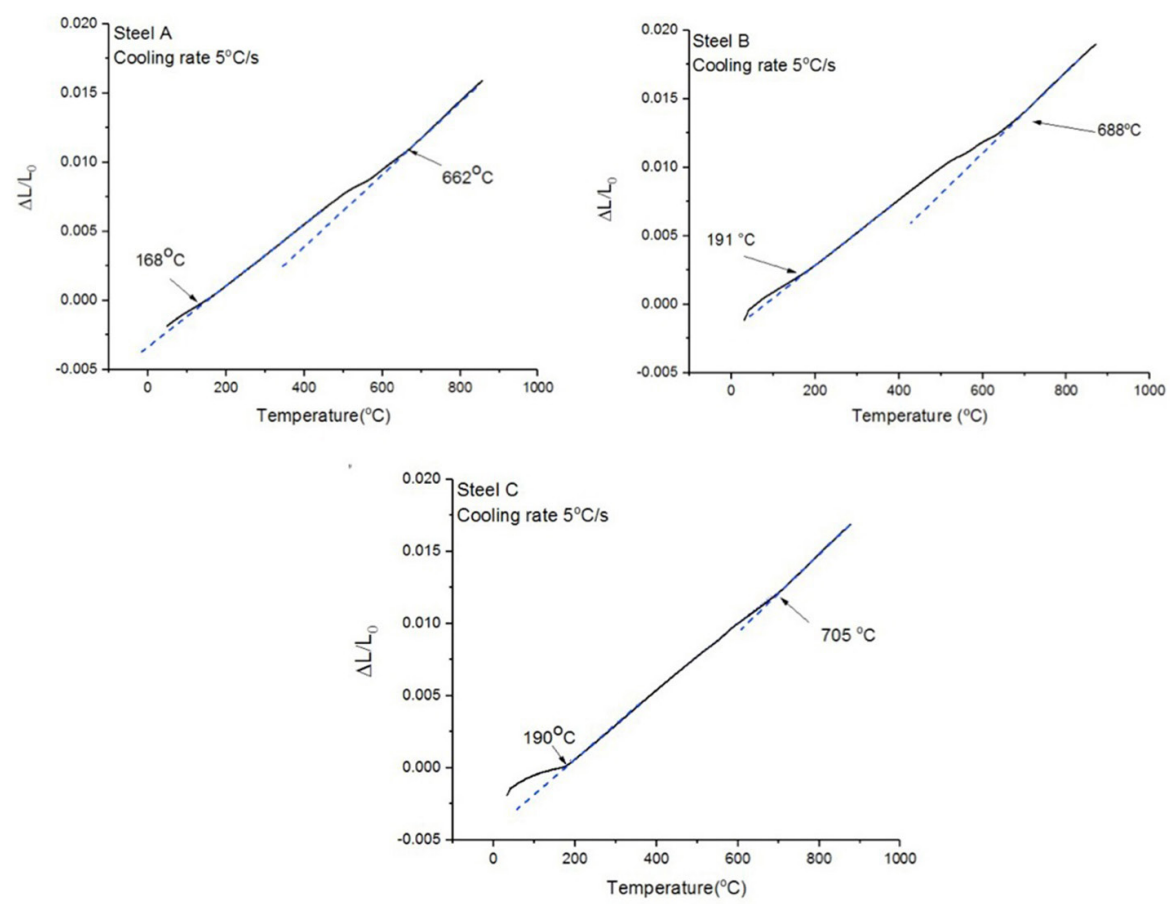

Figure 3. Comparison between the cooling dilatometric curves for steels $\mathrm{A}, \mathrm{B}$ and $\mathrm{C}$ cooled at $5^{\circ} \mathrm{C} / \mathrm{s}$.



Figure 4. Experimentally determined CCT diagrams of steels A, $\mathrm{B}$ and C. Austenitizing temperature: $900^{\circ} \mathrm{C}$.

where martensitic transformation started to occur $\left(\mathrm{M}_{\mathrm{s}}\right)$. For steels A, B and C, cooled at $5^{\circ} \mathrm{C} / \mathrm{s}$, the $\mathrm{M}$ temperatures were, respectively, $168^{\circ} \mathrm{C}, 191^{\circ} \mathrm{C}$ and $190^{\circ} \mathrm{C}$. Based on this minimal deviation method, the critical temperatures $\mathrm{P}_{\mathrm{i}}, \mathrm{P}_{\mathrm{f}}$ and $M_{s}$ were determined for each evaluated cooling rates and it was possible to plot the experimental continuous cooling transformation (CCT) diagrams for the studied steels, austenitized at $900^{\circ} \mathrm{C}$. Figure 4 presents a comparison between them.

Comparing the measured CCT diagrams, it is possible to observe that the premium steel ones is slightly shifted down in relation to the standard steel one. In general, the initial temperature of austenite to pearlite $\left(\mathrm{P}_{\mathrm{i}}\right)$ decomposition is lower the higher the alloying element content in steel, i.e. the kinetic effects of most elements added to steel shift the CCT diagram to right and down ${ }^{26,49,50}$. However, in this study case, it was verified that the standard steel, which has the highest alloying element content, is not the steel with the most right-down shifted diagram. The pearlite nucleation in premium steels were delayed in relation to the standard one. This behaviour can be explained regarding to the prior austenite grains at the studied austenitizing condition. During austenite continuous cooling, the austenite boundaries are preferential sites for diffusional constituent nucleation, as pearlite. Therefore, the smaller the prior austenite grains the higher the total grain boundary surface and thus the higher the preferential sites for pearlite nucleation. According to some researchers ${ }^{3,10,51}$, in steels with similar chemical effects, as those here studied according to Rodrigues et al. ${ }^{2}$, the prior austenite grain size has a relevant effect on critical temperatures measured in continuous cooling phase transformation, especially for higher cooling rates where diffusion is increasingly difficult. According to them, the start temperature of austenite to a diffusional constituent decomposition is higher the smaller the prior austenite grain size, especially for relatively high cooling rates, as observed for the studied steels.

Aiming to characterize the effect of cooling rate on final microstructures, the samples submitted to $0.5^{\circ} \mathrm{C} / \mathrm{s}, 2.5^{\circ} \mathrm{C} / \mathrm{s}$ and $10^{\circ} \mathrm{C} / \mathrm{s}$ were microstructurally characterized for the three studied steels. Figures 5, 6 and 7 present, respectively, the micrographs obtained for $0.5^{\circ} \mathrm{C} / \mathrm{s}, 2.5^{\circ} \mathrm{C} / \mathrm{s}$ and $10^{\circ} \mathrm{C} / \mathrm{s}$. In the same way, Table 4 shows the quantitative microstructural characteristics and Vickers microhardness. It can be observed that, for all studied materials, the samples submitted to $0.5^{\circ} \mathrm{C} / \mathrm{s}$ and $2.5^{\circ} \mathrm{C} / \mathrm{s}$ cooling rates presented fully pearlitic microstructures, whereas the samples cooled at $10^{\circ} \mathrm{C} / \mathrm{s}$ produced mixed microstructures, composed of pearlite and martensite. These micrographs confirmed what was already verified in the dilatometric curves of steels $\mathrm{A}, \mathrm{B}$ and $\mathrm{C}$, and subsequently presented in CCT diagrams. 

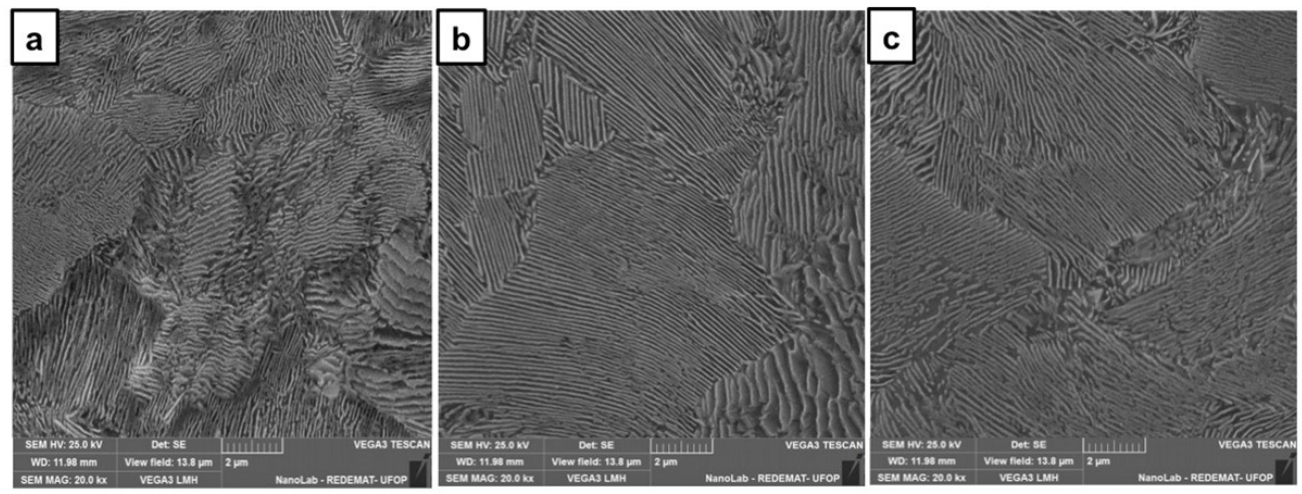

Figure 5. Micrographs of steels A (a), B (b) and C (c) submitted to $0.5^{\circ} \mathrm{C} / \mathrm{s}$ cooling rate - SEM - $20.000 \mathrm{X}-2 \%$ Nital etching.
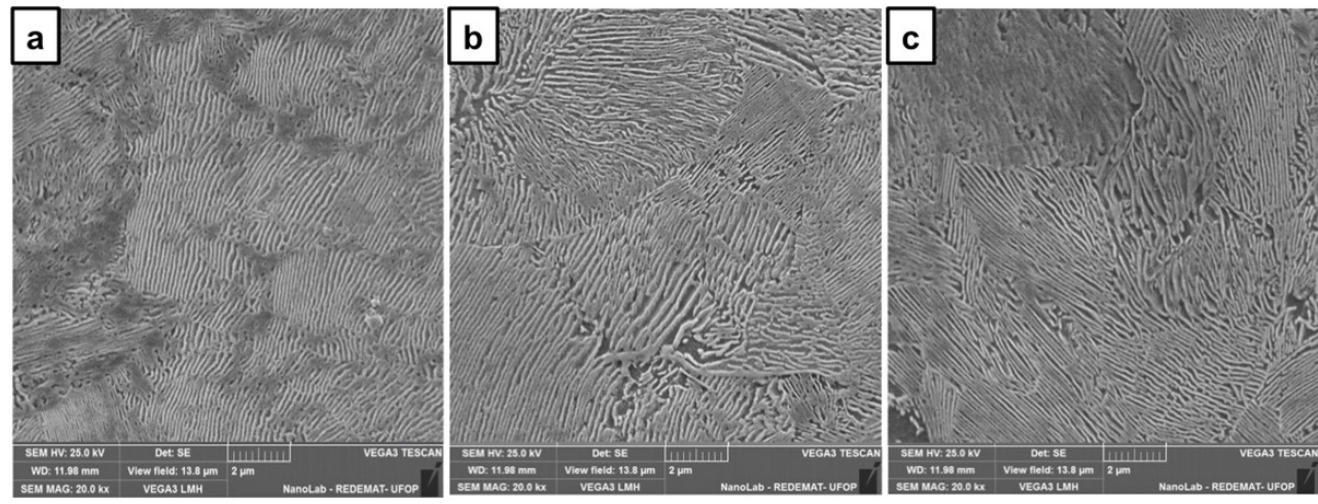

Figure 6. Micrographs of steels A (a), B (b) and C (c) submitted to $2.5^{\circ} \mathrm{C} / \mathrm{s}$ cooling rate - SEM - $20.000 \mathrm{X}-2 \%$ Nital etching.
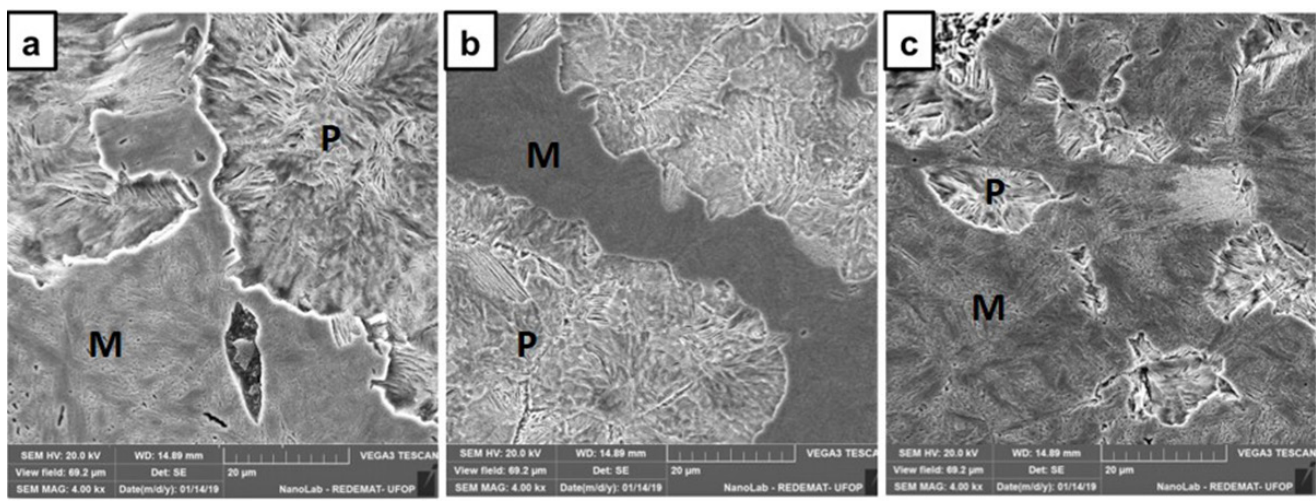

Figure 7. Micrographs of steels A (a), B (b) and C (c) submitted to $10^{\circ} \mathrm{C} / \mathrm{s}$ cooling rate - SEM - $4.000 \mathrm{X}-2 \%$ Nital etching (P - Pearlite, $\mathrm{M}$ - Martensite).

Table 4. Pearlite colony size, pearlite interlamellar spacing and Vickers microhardness of studied steels submitted to $0.5^{\circ} \mathrm{C} / \mathrm{s}$ and $2.5^{\circ} \mathrm{C} / \mathrm{s}$ cooling rates; Vickers microhardness of samples submitted to $10^{\circ} \mathrm{C} / \mathrm{s}$ cooling rate.

\begin{tabular}{|c|c|c|c|c|}
\hline Rate & Steel & Pearlite colony size $(\mu \mathrm{m})$ & $\begin{array}{l}\text { Pearlite interllamelar } \\
\text { spacing }(\mu \mathrm{m})\end{array}$ & Vickers Hardness (HV) \\
\hline \multirow{3}{*}{0.5} & A & $10 \pm 1.0$ & $0.09 \pm 0.02$ & $375 \pm 13$ \\
\hline & $\mathrm{B}$ & $9 \pm 1.0$ & $0.10 \pm 0.01$ & $348 \pm 12$ \\
\hline & $\mathrm{C}$ & $9 \pm 0.9$ & $0.09 \pm 0.01$ & $344 \pm 12$ \\
\hline \multirow{3}{*}{2.5} & $\mathrm{~A}$ & $5 \pm 0.7$ & $0.09 \pm 0.01$ & $417 \pm 15$ \\
\hline & $\mathrm{B}$ & $5 \pm 0.7$ & $0.08 \pm 0.01$ & $398 \pm 21$ \\
\hline & $\mathrm{C}$ & $6 \pm 0.8$ & $0.08 \pm 0.01$ & $377 \pm 12$ \\
\hline \multirow{3}{*}{10} & $\mathrm{~A}$ & - & - & $616 \pm 109$ \\
\hline & $\mathrm{B}$ & - & - & $668 \pm 197$ \\
\hline & $\mathrm{C}$ & - & - & $917 \pm 50$ \\
\hline
\end{tabular}


Evaluating the obtained results for the three studied steels, it is possible to state that the average pearlite colony size of samples submitted to $2.5^{\circ} \mathrm{C} / \mathrm{s}$ cooling rate were lower than the ones cooled at $0.5^{\circ} \mathrm{C} / \mathrm{s}$ and significantly lower than the samples in the as manufactured condition (Table 2). According to several published studies ${ }^{2,3,9,10,49-52}$, the pearlite colony size is strongly influenced by the prior austenite grain size and the cooling rate, in a way that the smaller the austenitic grain size and the higher the cooling rate, the smaller the pearlite colony size. Comparing the heat treated samples (Table 4) with the as manufactured ones (Table 2), it is possible to justify the great differences in pearlite colony sizes mainly due to the differences in austenitizing temperatures, considering that the usual cooling rates after hot rolling are between $0.5^{\circ} \mathrm{C} / \mathrm{s}$ and $3{ }^{\circ} \mathrm{C} / \mathrm{s}$ for the most of eutectoid rail steels ${ }^{3}$. The rail hot rolling is not a thermomechanical control process (TMCP) and the usual austenitizing temperature at the rolling beginning is higher than $1100^{\circ} \mathrm{C}$. This relatively high austenitizing temperature, compared to the one evaluated in this study, certainly contributed to the austenite grain growth and, considering that in rail hot rolling there will be no a strong grain refinement due to austenite recrystallization, it consequently contributed to the higher verified pearlite colony sizes. This result highlights that, with the aim to design rail steel heat treatment it is important to consider the austenite grain size prior to steel cooling.

Comparing the studied steels, it was verified that despite steel $\mathrm{C}$ had the smallest austenite grain size for the same austenitizing condition, there is no significant differences between the pearlite colony sizes as it was verified for steels $\mathrm{A}$ and $\mathrm{B}$. This can be explained due to the stronger effect of cooling rate on critical temperatures observed in steels A and B. According to diffusional nucleation and growth theory ${ }^{26,49}$, the higher the cooling rate the higher the austenite supercooling and, therefore, the higher the driving force for austenite to pearlite transformation. As the critical radius of pearlite nucleus is inversely proportional to the driving force, it can be stated that the higher the austenite supercooling the lower the pearlite critical radius, which increases the pearlite nucleation rate and contribute to pearlite colony refinement. This, in association with the fact that increasing the cooling rate and, then, lowering the austenite to pearlite transformation temperature, the energy available for diffusional growth also decreases, slowing the transformation kinetic ${ }^{26,49,53}$, it is expected that the higher the cooling rate effect on austenite supercooling, the lower the pearlite colony sizes, as well as this explain the similarity in pearlite colony sizes for the studied steels cooled in these conditions, i.e. for the same applied cooling rate, the austenite supercooling was higher in premium steels (A and B), justifying relatively small pearlite colonies even with their higher austenitic grain sizes in relation to the standard steel (C).

Regarding to pearlite interlamellar spacing, it was observed that premium steels submitted to $0.5^{\circ} \mathrm{C} / \mathrm{s}$ and $2.5^{\circ} \mathrm{C} / \mathrm{s}$ did not present significant differences in relation to their as manufactured conditions (comparing Tables 2 and 4). This result is coherent because during the rail manufacturing, steels A and B are submitted to controlled cooling after hot rolling, what does not happen with steel $\mathrm{C}^{2}$. In this way, it was expected that steel $\mathrm{C}$ presented the greater differences in pearlite interlamellar spacing comparing the as manufactured state with those submitted to $0.5^{\circ} \mathrm{C} / \mathrm{s}$ and $2.5^{\circ} \mathrm{C} / \mathrm{s}$ cooling rates. According to some authors $\mathrm{s}^{3,7,9,49}$, the pearlite interlamellar spacing is strongly influenced by austenite supercooling degree, i.e. the difference between the equilibrium and the non-equilibrium critical temperatures. According to them, the nucleation and growth of pearlite is mainly controlled by interstitial carbon diffusion through the austenite to the tips of the advancing cementite lamellae. With the cooling rate increase and, consequently, the austenite supercooling increase, the effective distance of carbon diffusion decreases and it is possible to show that the interlamellar spacing decreases inversely proportional to the supercooling degree. The obtained results are relevant because they show that applying a well-planned cooling procedure after the rail hot rolling, there is great potential to obtain microstructural characteristics for a standard steel so refined as those achieved for premium steels.

The premium steels, when submitted to $0.5^{\circ} \mathrm{C} / \mathrm{s}$ cooling rate, did not presented increase in hardness values $(375 \mathrm{HV}$ - steel A; $348 \mathrm{HV}$ - steel B) when compared to their as manufactured conditions (397HV - steel A; 361HV - steel B). However, the standard steel, for the same cooling rate, presented a great increase in its hardness value (344HV) compared to the as manufactured state $(325 \mathrm{HV})$. When submitted to $2.5^{\circ} \mathrm{C} / \mathrm{s}$, both premium and standard steels presented a significant rise in hardness, when compared to their as manufactured conditions (comparing Tables 2 and 4). According to Rodrigues et al. ${ }^{2}$, Porcaro et al. ${ }^{3}$ and Taleff et al. ${ }^{19}$, the heat treated pearlitic steels have their hardness significantly increased due to the microstructural refinement. In this context, it is possible to state that the verified hardness increase in steel $\mathrm{C}$ when submitted to $0.5^{\circ} \mathrm{C} / \mathrm{s}$ and $2.5^{\circ} \mathrm{C} / \mathrm{s}$ is due to the great microstructural refinement.

For the three evaluated steels, the hardness of the samples submitted to $10^{\circ} \mathrm{C} / \mathrm{s}$ cooling rate were relatively high. It is important to highlight that the steels $\mathrm{A}, \mathrm{B}$ and $\mathrm{C}$, cooled at this rate, presented mixed microstructures, constituted by pearlite and martensite. The standard steel presented the highest hardness value. This can be explained mainly due to the highest concentrations of alloying elements in this steel. According to Liu et al. ${ }^{45}$, elements as $\mathrm{Mn}$ and $\mathrm{Si}$ in solid solution delay the evolution of austenite to pearlite transformation. In this context, even with the smaller austenitic grains favouring the pearlite nucleation, the growth rate decreases and the metastable austenite fraction that arrives at Ms temperature is higher, forming a higher fraction of martensite. Finally, it is important to highlight that, as it was expected, for the three studied steels, the higher the applied cooling rate the higher the steel hardness. This is a consequence of the effect of the cooling rate on the microstructural evolution, as above described $^{2,3,19,26,31,33,45}$.

\subsubsection{Kinetics of austenite continuous cooling decomposition}

Considering the three studied steels, in the cooling rate range between $0.1^{\circ} \mathrm{C}$ and $2.5^{\circ} \mathrm{C} / \mathrm{s}$, where the transformation product is only pearlite, the fitting of Equation 3 (JMAK) to the pearlite fraction as a time function data, obtained by dilatometry, were performed resulting in $\mathrm{k}$ and $\mathrm{n}$ constants 
determination. Similarly, the Equation 4 (Ferrite-time) were also fitted and the constants $\mathrm{k}$ ', n' and $\mathrm{T}_{f}$ were calculated. All these parameters are presented in Table 5. Regarding to the calculated coefficient of determination $\left(\mathrm{R}^{2}\right)$ values, it is possible to affirm that, for all studied steels, the regression curves of Ferrite-time equation were closer to the experimental data than the JMAK one. Figures 8 to 10 highlight the fittings of Equations 3 and 4 to the experimental data obtained for steels A, B and C respectively. As expected ${ }^{26,33,37,43}$, the experimental data, as well as the fitted equations, highlighted that the higher the cooling rate, the lower the total time required for complete transformation.

As described in Materials and Methods, in order to evaluate the efficiency of the empirical Equation 5, proposed by Cezário et al..$^{33}$, aiming to easily predict critical temperatures, for each steel; the critical temperatures $\mathrm{P}_{i}$ and $\mathrm{P}_{\mathrm{f}}$ were plotted as a cooling rate function and Equation 5 was fitted to the experimental data. Figure 11 and Table 6 present the obtained results with $\mathrm{R}^{2}$ values always higher than 0.95 .

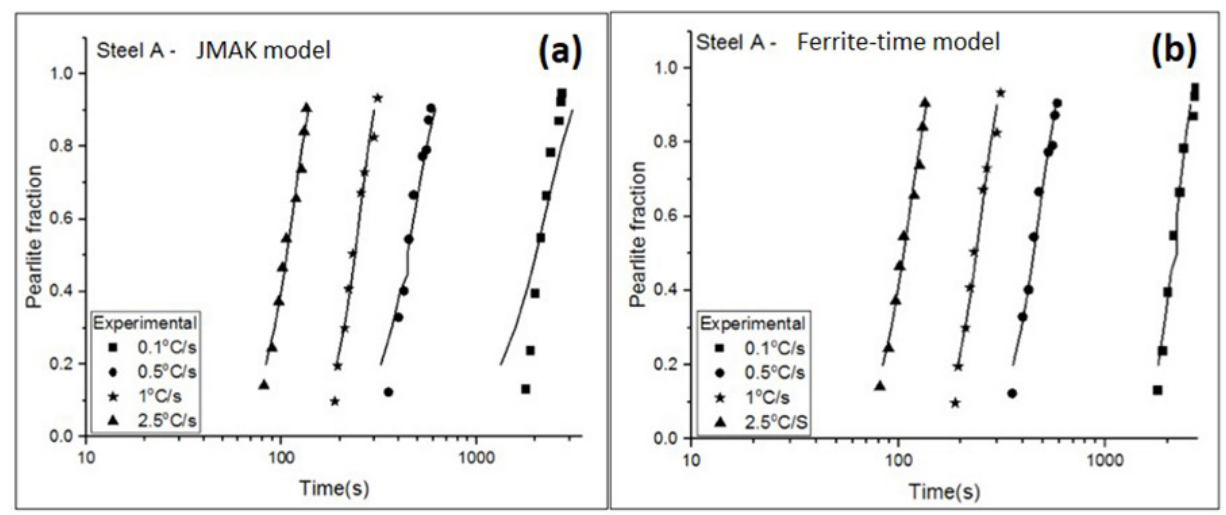

Figure 8. Pearlite fraction as a time function. (a) JMAK and (b) Ferrite-time equations fitted to the steel A experimental data.

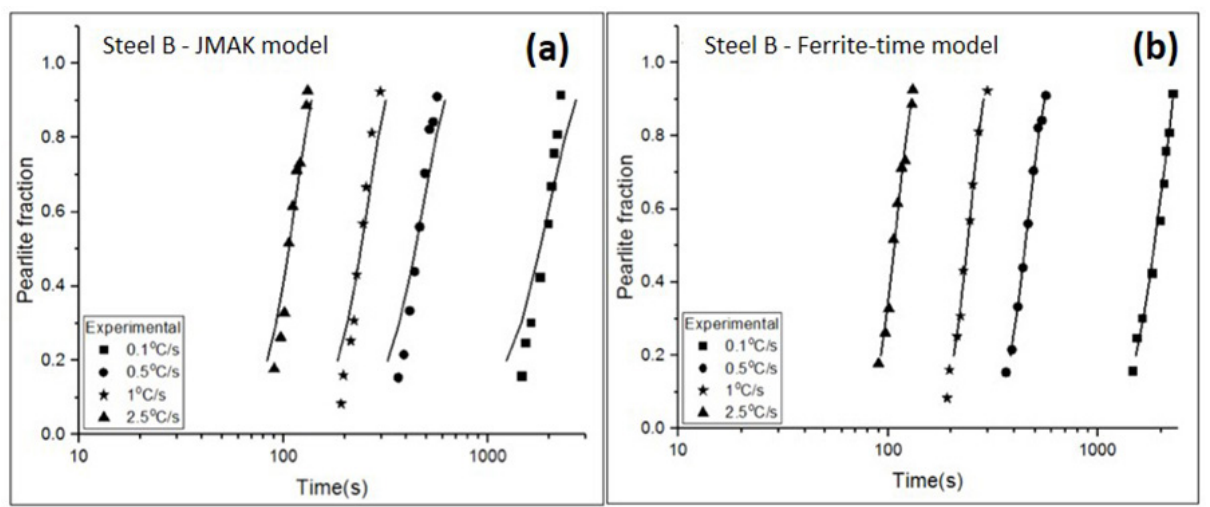

Figure 9. Pearlite fraction as a time function. (a) JMAK and (b) Ferrite-time equations fitted to the steel B experimental data.

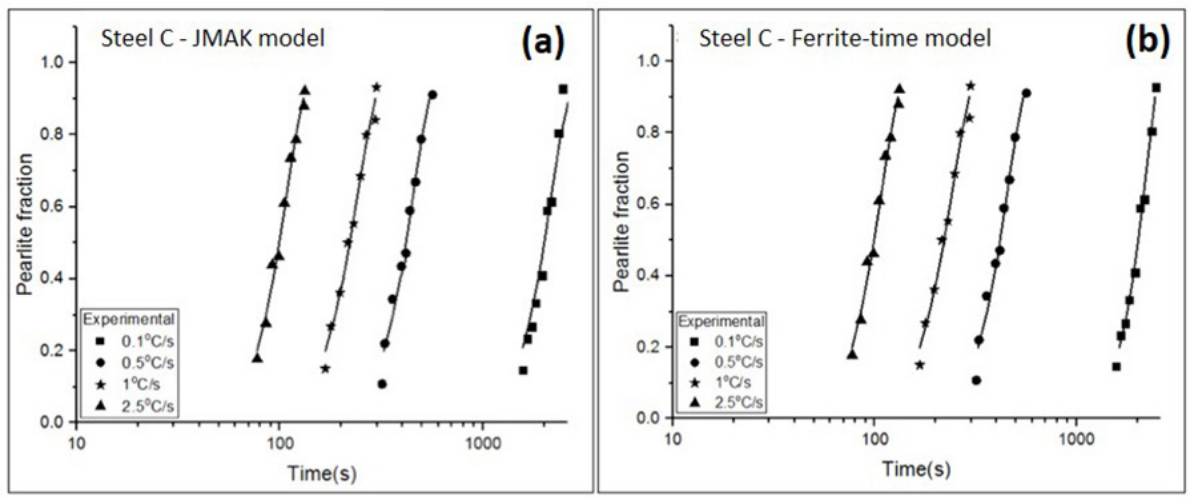

Figure 10. Pearlite fraction as a time function. (a) JMAK and (b) Ferrite-time equations fitted to the steel C experimental data. 
Table 5. Kinetics constants calculated through the fitting of Equations 3 and 4 to the experimental data measured for steels A, B and C.

\begin{tabular}{|c|c|c|c|c|c|c|c|c|}
\hline \multirow{2}{*}{ Steel } & \multirow{2}{*}{ Rate $\left({ }^{\circ} \mathrm{C} / \mathrm{s}\right)$} & \multicolumn{3}{|c|}{ JMAK } & \multicolumn{4}{|c|}{ Ferrite-Time } \\
\hline & & $\mathrm{K}$ & $\mathrm{n}$ & $\mathrm{R}^{2}$ & $\mathrm{~K}^{\prime}$ & n' & $\mathrm{T}_{\mathrm{f}}$ & $\mathrm{R}^{2}$ \\
\hline \multirow{4}{*}{ A } & 0.1 & 4.94E-10 & 2.77 & 0.74 & $1.0 \mathrm{E}-6$ & 2.941 & 591.76 & 0.98 \\
\hline & 0.5 & $1.45 \mathrm{E}-10$ & 3.660 & 0.93 & $2.45 \mathrm{E}-7$ & 2.798 & 546.06 & 0.97 \\
\hline & 1.0 & $2.0 \mathrm{E}-13$ & 2.277 & 0.97 & $7.41 \mathrm{E}-7$ & 2.840 & 536.36 & 0.97 \\
\hline & 2.5 & $2.86 \mathrm{E}-10$ & 4.631 & 0.97 & $5.86 \mathrm{E}-6$ & 3.242 & 810.45 & 0.98 \\
\hline \multirow{4}{*}{ B } & 0.1 & $1.35 \mathrm{E}-10$ & 2.983 & 0.83 & $1.73 \mathrm{E}-6$ & 2.816 & 617.27 & 0.98 \\
\hline & 0.5 & $1.92 \mathrm{E}-10$ & 3.613 & 0.87 & 4.33E-9 & 3.836 & 537.95 & 0.99 \\
\hline & 1.0 & $3.38 \mathrm{E}-11$ & 4.337 & 0.99 & $1.25 \mathrm{E}-6$ & 2.895 & 565.84 & 0.99 \\
\hline & 2.5 & $2.64 \mathrm{E}-10$ & 4.652 & 0.92 & $8.0 \mathrm{E}-7$ & 3.436 & 739.63 & 0.98 \\
\hline \multirow{4}{*}{$\mathrm{C}$} & 0.1 & $1.29 \mathrm{E}-15$ & 4.462 & 0.95 & $2.98 \mathrm{E}-4$ & 1.841 & 630.93 & 0.99 \\
\hline & 0.5 & $9.54 \mathrm{E}-13$ & 4.526 & 0.98 & $2.93 \mathrm{E}-6$ & 2.585 & 571.49 & 0.98 \\
\hline & 1.0 & $1.68 \mathrm{E}-10$ & 4.105 & 0.98 & $1.51 \mathrm{E}-6$ & 2.629 & 537.60 & 0.98 \\
\hline & 2.5 & $1.04 \mathrm{E}-10$ & 4.420 & 0.98 & $9.64 \mathrm{E}-7$ & 2.685 & 500.68 & 0.99 \\
\hline
\end{tabular}

Table 6. Empirical equations predicting critical temperature values as cooling rate functions (Equation 5).

\begin{tabular}{ccc}
\hline Steel & $\mathrm{P}_{\mathrm{i}}$ & $\mathrm{P}_{\mathrm{f}}$ \\
\hline $\mathrm{A}$ & $\mathrm{T}=698.33+64.18^{*} \exp (-1.12 * \mathrm{R})$ & $\mathrm{T}=528.31+100.58 \mathrm{~B} * \exp (-0.7 * \mathrm{R})$ \\
\hline $\mathrm{B}$ & $\mathrm{T}=698.43+92.18 * \exp (-1.52 * \mathrm{R})$ & $\mathrm{T}=563.51+118.99 * \exp (-1.66 * \mathrm{R})$ \\
\hline $\mathrm{C}$ & $\mathrm{T}=708.09+55.10 * \exp (-0.8 * \mathrm{R})$ & $\mathrm{T}=531.67+110.26 * \exp (-0.6 * \mathrm{R})$ \\
\hline
\end{tabular}

Evaluating the results presented in Table 6, it is possible to observe that the constant $\mathrm{B}$ in Equation 5 is related to the effect of cooling rate on $\mathrm{P}_{\mathrm{i}}$ and $\mathrm{P}_{\mathrm{f}}$ temperatures, i.e. the higher the $\mathrm{B}$ value modulus, the higher the decrease rate of critical temperature $(\mathrm{dP} / \mathrm{dR})$. This parameter highlight what had already been discussed in section 3.2.2, i.e. critical temperatures $\left(\mathrm{P}_{\mathrm{i}}\right.$ and $\left.\mathrm{P}_{\mathrm{f}}\right)$ of the premium steels is little more influenced by cooling rate than the ones of the standard, justifying the similar pearlite colony sizes despite $\mathrm{C}$ steel having the smallest prior austenite grain size. The parameter $\mathrm{y}_{0}$ in Equation 5 is related to the lowest critical temperature values when the cooling rate increases within the investigated range. In other words, this parameter indicates the lowest start and final transformation temperature. For example, regarding the experimental CCT diagram of steel C (Figure 4), it is possible to verify that at $2.5^{\circ} \mathrm{C} / \mathrm{s}$ (the highest cooling rate with fully pearlitic microstructure) $\mathrm{P}_{\mathrm{i}}=705^{\circ} \mathrm{C}$ and $\mathrm{P}_{\mathrm{f}}=540^{\circ} \mathrm{C}$, values very close than those predict by parameter $\mathrm{y}_{0}$ for steel $\mathrm{C}$, that were $708^{\circ} \mathrm{C}$ and $532^{\circ} \mathrm{C}$ respectively. This result, quantitatively reinforce another important discussion in section 3.2.2, when it was written that the smallest prior austenite grain size of steel $\mathrm{C}$ favoured the pearlite nucleation, however the pearlite growth rate in this steel is delayed due to its chemical composition. Comparing the $\mathrm{y}_{0}$ parameter values for all studied steels (Table 6) and the experimental CCT diagram (Figure 4), it is possible to observe that the $\mathrm{P}_{\mathrm{i}}$ values for steel $\mathrm{C}$ is, in general, higher than the ones determined for premium steels. However, this behaviour does not repeat for $\mathrm{P}_{\mathrm{f}}$ values, indicating that although the transformation begins at higher temperatures for steel $\mathrm{C}$, it will not end at higher temperatures, but rather similar to steel $\mathrm{A}$ and $\mathrm{B}$.

In order to verify the representativeness of the evaluated equations to predict the steel continuous cooling transformations, CCT diagrams were simulated using them. The obtained results were compared with experimentally determined CCT diagrams. As already described in Materials and Methods, for JMAK and Ferritetime equations, the $\mathrm{P}_{\mathrm{i}}$ and $\mathrm{P}_{\mathrm{f}}$ temperatures were calculated using, respectively, $\mathrm{X}=\mathrm{y}=0.02$ and $\mathrm{X}=\mathrm{y}=0.9$ in Equations 3 and 4 (considering the fitting constants presented in Table 5). For Empirical Model, the fitting constants presented in Table 6 were directly applied to Equation 5, so that $\mathrm{P}_{\mathrm{i}}$ and $\mathrm{P}_{\mathrm{f}}$ values were calculated as a cooling rate function and the time was then calculated by applying Equation 2. In this context, for each steel, three CCT diagrams were calculated and compared with the experimental ones as Figure 12 highlights. In the face of these results, it can be stated that, for steels $\mathrm{A}, \mathrm{B}$ and $\mathrm{C}$, the three evaluated equations in order to predict the CCT diagrams were satisfactory. However, comparing the three models, the predicted values that came closest to those experimentally determined, were the calculated using Empirical Model proposed by Cezário et al. ${ }^{33}$ (Equation 5). 

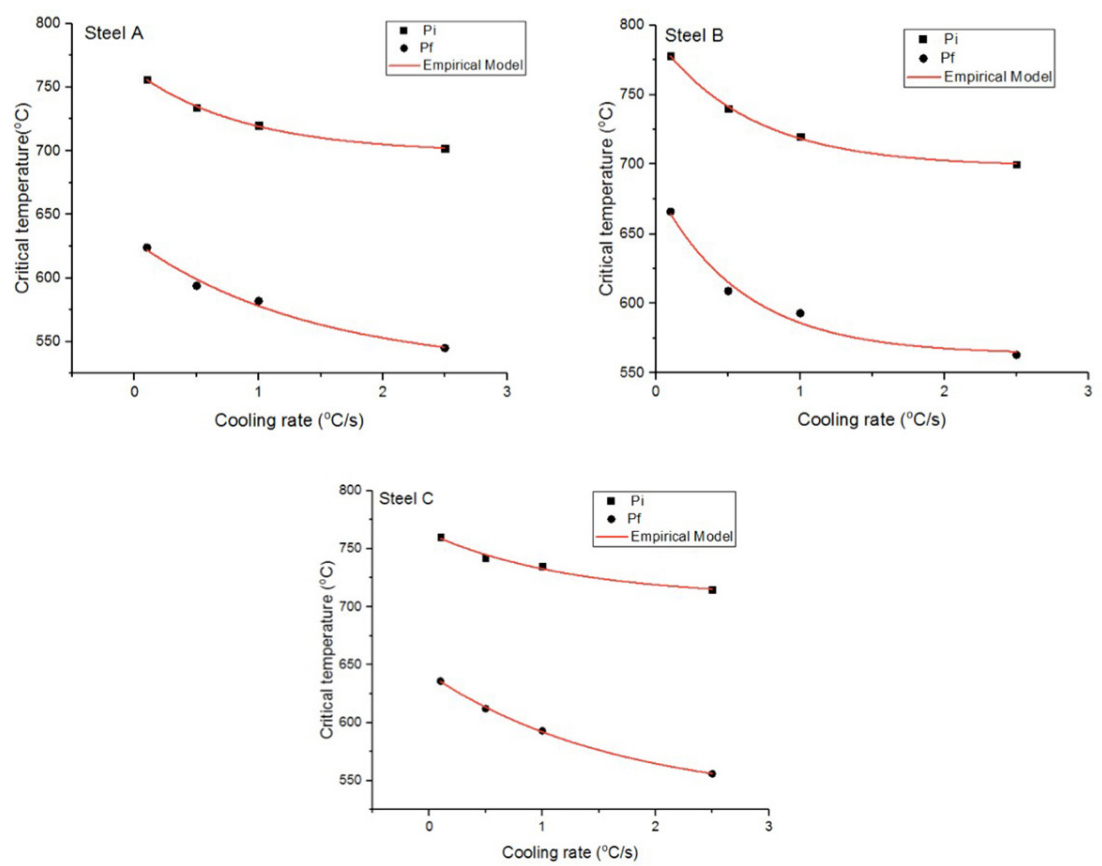

Figure 11. Critical temperatures as cooling rate functions. Empirical model fitted to the experimental data measured for steels A, B and C.
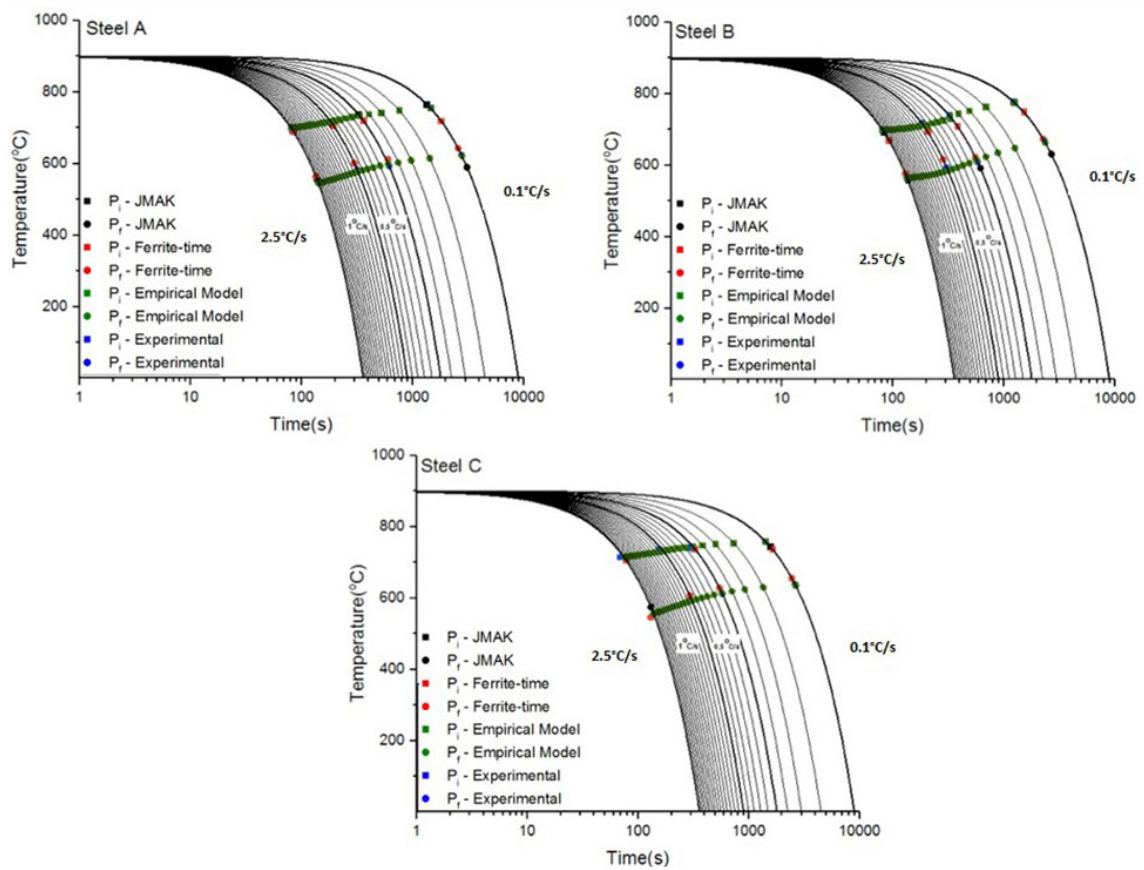

Figure 12. Calculated and experimental CCT diagrams of steels A, B and C.

\section{Conclusions}

The three studied steels, in the as manufactured conditions, have fully pearlitic microstructures, being premium steels the more refined ones. Considering the same full austenitizing condition, the standard steel presented the lowest prior austenite grain size. This occurred due to its lowest initial pearlite interlamellar spacing in association with its higher $\mathrm{Mn}, \mathrm{Nb}$ and $\mathrm{Si}$ contents (drag and precipitate effects).

For all evaluated steels, the critical cooling rate, i.e. the higher cooling rate which yet propitiates a fully pearlitic microstructure, is $2.5^{\circ} \mathrm{C} / \mathrm{s}$. The minor prior austenite grain size of the standard steel favored the pearlite nucleation, rising up the $\mathrm{P}_{\mathrm{i}}$ temperatures in relation to the premium 
ones. However, due to its highest $\mathrm{Mn}$ and $\mathrm{Si}$ contents, the standard $\mathrm{P}_{\mathrm{f}}$ temperatures were close to the ones measured for the premium steels.

The three equations evaluated in order to predict the kinetics of austenite to pearlite transformation under continuous cooling were satisfactory. In general, regarding to the calculated coefficient of determination values, it is possible to affirm that, for all studied steels, the fitted curves of Ferrite-time equation were closer to the experimental data than the JMAK ones. The Empirical Model proposed by Cezário et al. ${ }^{33}$ stood out as a relatively simple and efficient predicting tool. This is a low complexity method which allowed predicting, with good agreement, the critical transformation temperatures as a cooling rate function and, therefore, the CCT diagrams of the studied steels.

\section{Acknowledgments}

The authors would like to thank the Conselho Nacional de Desenvolvimento Científico e Tecnológico $(\mathrm{CNPq})$ and Universidade Federal de Ouro Preto for the financial support.

\section{REFERENCES}

1. Bauri LF, Alves LHD, Pereira HB, Tschiptschin AP, Goldenstein $\mathrm{H}$. The role of welding parameters on the control of the microstructure and mechanical properties of rails welded using FBW. Journal of Materials Research and Technology. 2020;9(4):8058-73.

2. Rodrigues KF, Mourão GMM, Faria GLF. Kinetics of isothermal phase transformations in premium and standard rail steels. Steel Res Int. 2021;92(2):2000306. http://dx.doi.org/10.1002/ srin.202000306.

3. Porcaro RR, Faria GL, Godefroid LB, Apolonio GR, Candido LC, Pinto ES. Microstructure and mechanical properties of a flash buttwelded pearlitic rail. J Mater Process Technol. 2019;270:20-7.

4. Godefroid LB, Moreira LP, Vilela TCG, Faria GL, Candido LC, Pinto ES. Effect of chemical composition and microstructure on the fatigue crack growth resistance of pearlitic steels for railroad application. Int J Fatigue. 2019;120:241-53.

5. Nishikawa LP, Goldenstein H. Divorced eutectoid on heataffected zone of welded pearlitic rails. JOM. 2019;71(2):815-23.

6. Sahay S, Mohapatra G, Totten G. Overview of Pearlitic Rail Steel: accelerated cooling, quenching, microstructure, and mechanical properties. J ASTM Int. 2009;6(7):1-26.

7. Wang M, Zhang F, Yang Z. Effects of high-temperature deformation and cooling process on the microstructure and mechanical properties of an ultrahigh-strength pearlite steel. Mater Des. 2017;114(15):102-10.

8. Offerman SE, van Wilderen LJGW, van Dijk NH, Sietsma J, Rekveldt MT, van der Zwaag S. In-situ study of pearlite nucleation and growth during isothermal austenite decomposition in nearly eutectoid steel. Acta Mater. 2003;51(13):3927-38.

9. Marder AR, Bramfitt BL. The effect of morphology on the strength of pearlite. Metall Trans, A, Phys Metall Mater Sci. 1976;7(3):365-72.

10. Hyzak JM, Bernstein IM. The role of microstructure on the strength and toughness of fully pearlitic steels. Metall Trans, A, Phys Metall Mater Sci. 1976;7(8):1217-24.

11. Dollar M, Bernstein IM, Thompson AW. Influence of deformation substructure on flow and fracture of fully pearlitic steel. Acta Metall. 1988;36(2):311-20.
12. AREMA: American Railway Engineering and Maintenance-ofWay Association. Manual for railway engineering. Maryland: AREMA; 2013.

13. Godefroid LB, Faria GL, Cândido LC, Viana TG. Failure analysis of recurrent cases of fatigue fracture in flash butt welded rails. Eng Fail Anal. 2015;58(2):407-16.

14. Cannon DF, Edel KO, Grassie SL, Sawley K. Rail defects: an overview. Fatigue Fract Eng Mater Struct. 2003;26(10):865-86.

15. Rice RC. Shell and detail fracture formation in railroad rails. In: Stephens RI, editor. ASTM STP 1250: case studies for fatigue education. Philadelphia: American Society for Testing and Materials; 1994. p. 109-38.

16. Li YD, Liu CB, Xu N, Wu XF, Guo WM, Shi JB. A failure study of the railway rail serviced for heavy cargo trains. Case Stud Eng Fail Anal. 2013;1(4):243-8.

17. Lee KM, Polycarpou AA. Wear of conventional pearlitic and improved bainitic rail steels. Wear. 2005;259(1-6):391-9.

18. Tressia G, Sinatora A, Goldenstein H, Masoumi M. Improvement in the wear resistance of a hypereutectoid rail via heat treatment. Wear. 2020;442-443:203122.

19. Taleff EM, Lewandowski JJ, Pourladian B. Microstructureproperty relationships in pearlitic eutectoid and hypereutectoid carbon steels. J Mater. 2002;54:25-30.

20. American Society for Testing and Materials - ASTM. ASTM E3: standard guide for preparation of metallographic specimens. West Conshochen: ASTM; 2017.

21. American Society for Testing and Materials - ASTM. ASTM E112: standard test methods for determining average grain size. West Conshochen: ASTM; 2014.

22. Gomes MGMF, Almeida LH, Gomes LCFC, May IL. Effects of microstructural parameters on the mechanical properties of eutectoid rail steels. Mater Charact. 1997;39(1):1-14.

23. García de Andrés C, Caballero FG, Capdevila C, Álvarez LF. Application of dilatometric analysis to the study of solid-solid phase transformations in steels. Mater Charact. 2002;48(1):10111.

24. Faria G, Cardoso R, Moreira P. Development of an oxidation method for prior austenite grain boundary revelation. Metall Microstruct Anal. 2018;7:533-41.

25. American Society for Testing and Materials - ASTM. ASTM E1382: standard test methods for determining average grain size using semiautomatic and automatic image analysis. West Conshochen: ASTM; 2015.

26. Cardoso RA, Faria GL. Characterization of austenite decomposition in steels with different chemical concepts and high potential to manufacture seamed pipes for oil and gas industry. Mater Res. 2019;22(5):e20190378.

27. Cho Y, Im Y, Lee JK, Suh D, Kim S, Han HN. A finite element modeling for dolatometric non-isotropy in steel. Metall Mater Trans, A Phys Metall Mater Sci. 2011;42(7):2094-106.

28. Lei X, Huang J, Jin X, Chen S, Zhao X. Application of JohnsonMehl-Avrami-Kolmogorov type equation in non-isothermal phase process: re-discussion. Mater Lett. 2016;181:240-3.

29. Bok HH, Kim SN, Suh DW, Barlat F, Lee MG. Non-isothermal kinetics model to predict accurate phase transformation and hardness of 22MnB5 boron steel. Mater Sci Eng A. 2015;626(73):67-73.

30. Singh SB, Krishnan K, Sahay SS. Modeling non-isothermal austenite to ferrite transformation in low carbon steels. Mater Sci Eng A. 2007;445-446:310-5.

31. Cezário ALS. Caracterização e avaliação de modelos de previsibilidade da cinética de transformação de fases austenita/ ferrita de três aços IF [dissertation]. Ouro Preto: Rede Temática em Engenharia de Materiais, Universidade Federal de Ouro Preto; 2018.

32. Kohout J. An alternative to the JMAK equation for a better description of phase transformation kinetics. J Mater Sci. 2008;43(4):1334-9. 
33. Cezário ALS, Porcaro RR, Faria GL. Proposition of an empirical model for determination of critical temperatures during continuous cooling in heat affected zones of IF steels welded by the TIG Process. Soldag Insp. 2019;24:1-14.

34. Trzaska J. Empirical formulae for the calculation of austenite supercooled transformation temperatures. Arch Metall Mater. 2015;60(1):181-5.

35. Pohjonen A, Somani M, Porter D. Modelling of austenite transformation along arbitrary cooling paths. Comput Mater Sci. 2018;150:244-51.

36. Carlone P, Palazzo GS, Pasquino R. Finite element analysis of the steel quenching process: temperature field and solid-solid phase change. Comput Math Appl. 2010;59(1):585-94.

37. Umemoto M, Horiuchi K, Tamura I. Pearlite transformation during continuous cooling and its relation to isothermal transformation. Trans. Iron and Steel Inst. Jpn. 1983;23(8):690-5. http://dx.doi. org/10.2355/isijinternational1966.23.690.

38. Ye JS, Hsu TY, Chang HB. On the application of the additivity rule in pearlitic transformation in low alloy steels. Metall Mater Trans, A Phys Metall Mater Sci. 2003;34(6):1259-64.

39. Han J, Silva AK, Ponge D, Raabe D, Lee SM, Lee YK, et al. The effects of prior austenite grain boundaries and microstructural morphology on the impact toughness of intercritically annealed medium Mn steel. Acta Mater. 2017;122:199-206.

40. Zhao H, Wynne BP, Palmiere EJ. Effect of austenite grain size on the bainitic ferrite morphology and grain refinement of a pipeline steel after continuous cooling. Mater Charact. 2017;123:128-36.

41. Caballero FG, Capdevila C, García de Andrés C. Modelling of isothermal formation of pearlite and subsequent reaustenitisation in eutectoid stell during continuous heating. Mater Sci Technol. 2001;17(6):686-92.

42. Roósz A, Gacsi Z, Fuchs EG. Isothermal formation of austenite in eutectoid plain carbon steel. Acta Metall. 1983;31(4):509-17.

43. Khan AR, Yu S, Wang H, Jiang Y. Effect of cooling rate on microstructure and mechanical properties in the CGHAZ of electroslag welded pearlitic rail steel. Metals. 2019;9(7):742.

44. Zhang G, Chae J, Kim K, Suh DW. Effects of Mn, Si and Cr addition on the dissolution and coarsening of pearlitic cementite during intercritical austenitization in $\mathrm{Fe}-1$ mass $\% \mathrm{C}$ alloy.
Mater Charact. 2013;81:56-67. http://dx.doi.org/10.1016/j. matchar.2013.04.007.

45. Liu Q, Sun Z, Jia A, Zhang L, Huang G, Ren Y. Austenitization beahaviors of X80 pipeline steel with high $\mathrm{Nb}$ and trace $\mathrm{Ti}$ treatment. J Iron Steel Res Int. 2009;16(6):58-62.

46. Far ARH, Anijdan SHM, Abbasi M. The effect of $\mathrm{Ni}$ and $\mathrm{Cu}$ addition on mechanical behavior of thermomecanically controlled processed HSLA X100 steels. In: The Minerals Metals \& Materials Society, editor. TMS 2019 148th Annual Meeting \& Exhibition Suplemental Proceedings. Cham: Springer; 2019. p. $579-90$.

47. Mousavi Anijdan SH, Sediako D, Yue S. Optimization of flow stress in cool deformed $\mathrm{Nb}$-microalloyed steel by combining strain induced transformation of retained austenite, cooling rate and heat treatment. Acta Mater. 2012;60(3):1221-9. http:// dx.doi.org/10.1016/j.actamat.2011.11.019.

48. Anijdan SHM, Sabzi M. The evolution of microstructure of an high Ni HSLA X11 forged steel slab by thermomechanical controlled processing. In: The Minerals Metals \& Materials Society, editor. TMS $2018147^{\text {th }}$ Annual Meeting \& Exhibition. Cham: Springer; 2018. p. 145-56.

49. Bhadeshia HKDH, Honeycombe R. Steels: microstructure and properties. 4th ed. Oxford: Elsevier; 2017.

50. Anijdan SHM, Sanjari M, Yue S. Effects of cooling rate and cool deformation on mechanical properties and microstructure of a hot rolled Nb-microalloyed steel. In: Materials Science and Technology (MS\&T): Steel Processing, Product and Applications Symposium; 2009; Pittsburgh. Proceedings. Pittsburgh: The American Ceramic Society; 2009;1308.

51. Fernández-Vicente A, Carsí M, Peñalba F, Taleff E, Ruano OA. Toughness dependence on the microstructural parameters for an ultrahigh carbon steel (1.3 wt.\% C). Mater Sci Eng A. 2002;335(1-2):175-85.

52. Lewandowski JJ, Thompson AW. Effects of the prior austenite grain size on the ductility of fully pearlitic eutectoid steel. Metall Trans, A, Phys Metall Mater Sci. 1986;17(3):461-72.

53. Gouné M, Danoix F, Ågren J, Bréchet Y, Hutchinson CR, Militzer $\mathrm{M}$, et al. Overview of the current issues in austenite to ferrite transformation and the role of migrating interfaces therein for low alloyed steels. Mater Sci Eng Rep. 2015;92:1-38. 